$m o b$ genes of the small non-conjugative plasmid, RSF1010, can substitute for the requirement for a T-DNA border for transfer to plant cells. They used $A$. tumefaciens strains containing a helper plasmid to supply vir functions in trans, and one or other of a variety of small plasmids constructed in vitro and encoding a kanamycin-resistance gene capable of expression in plants. Plant tissue infected by such strains grows on media containing kanamycin if the resistance gene is transferred to the plant genome.

These experiments showed: (1) plasmids containing both oriT and mob will transfer the drug marker to plant tissue with similar frequencies to plasmids containing the T-DNA borders; (2) the oriT sequence alone is neither sufficient for DNA transfer to plants nor for conjugal transfer of the plasmid to a recipient bacterium; and (3) transfer in both cases is restored by supplying mob functions in trans from a third plasmid. Also, in vitro transcription and translation experiments show that three proteins are encoded in the RSF1010 mob region, and an in vitrogenerated frameshift mutation in the largest coding region abolishes DNA transfer to plants.

These results are important for the construction of the next generation of $\mathrm{Ti}$ plasmid-based vectors for plant genetic engineering. Ironically, it was previously supposed that the inclusion of T-DNA borders was essential. Clearly, this requirement is now obviated. These results also raise some interesting biological questions. Do plasmids with oriT and mob of RSF1010 still require the virD-encoded endonuclease? One prediction is that they do not, unless this endonuclease has additional functions specific for T-strand synthesis and/or transfer. Can a T-DNA border plus vir $D$ replace the requirement for $m o b$ and oriT in plasmid conjugation? How general is the phenomenon they have revealed: are other plasmids similarly transferred by $A$. tumefaciens to plants? If so, there are profound implications for the role bacteria might have played in plant evolution. The agrobacterial/plant interaction has always been presumed to be unique; however, might other prokaryotes have the ability to transfer conjugally specific DNA elements to particular target eukaryotes?

\footnotetext{
1. Lichtenstein, C. \& Fuller, S.L. in Genetic Engineering Vol 6 (ed. Rigby, P.W.J.) Ch.3 (Academic, London, 1987)

Stachel, S.F., Timmerman, B. \& Zambryski, P. Nature 322 $706-712(1986)$

. Buchanan-Wollaston, V., Passiator, J.E. \& Cannon, F. (1987)

A. \& Minkley, E.G. A. Rev. Genet. 20, 593 $624(1986)$

Stachel, Sessens, E. Van Montagu, M. \& Zambryski, P.C. Nature 318, 624-629(1985)

Stachel, S.E. \& Nester, E.W. EMBO J. 5, 1445-1454 (1986)

Yanofsky, M.F. et al. Cell 47, 471-477 (1986)

Wang, K, et al. Science 235, $587-591$ (1987)

. Stachel, S.E., Timmerman, B. \& Zambryski, P.C. EMBO J. 6, 857-863(1987).
}

Conrad Lichtenstein is in the Centre for Biotechnology, Imperial College of Science and Technology, London SW7 2AZ, UK.

Mass extinctions

\title{
How sudden is sudden?
}

\section{Stephen K. Donovan}

THE essential feature of a mass extinction, as seen in the fossil record, is that many organisms or groups of organisms die out during a period that is geologically instantaneous, even though it may represent many years in real terms. Our understanding, however, of such sudden geological events is often confused by the use of a coarse geological timescale, where all the organisms that disappeared during a particular era are lumped together, whether they died before, during or after the mass extinction. Detailed interpretation of the fossil record of certain groups of extinct molluscs shows that a large extinction event about 65 million years ago, that at the Cretaceous-Tertiary (K/T) boundary, attributed to the effects of a single bolide (meteor) impact, was preceded by a pattern of smaller disappearances.

A particularly complete $\mathrm{K} / \mathrm{T}$ boundary sequence is exposed in a superb coastal outcrop at Zumaya, north Spain. Detailed studies of bivalves and ammonites (an extinct group of cephalopods) from this section reveal an unexpected pattern of extinction ${ }^{1}$. The novelty of this approach is that most $\mathrm{K} / \mathrm{T}$ boundary sections are defined on the basis of microfossils and/or dinosaurs.

At Zumaya, oyster-like inoceramid bivalves, whose fossils are large and distinctive even when fragmentary, died out during the last 8 million years of the Cretaceous era, the Maastrichtian. The orthodox view now is that this group became extinct at the $\mathrm{K} / \mathrm{T}$ boundary, yet its demise seems to predate this event by several million years. Perhaps stranger still is the pattern of ammonite distribution at the top of the Cretaceous section. There are three hitherto unrecognized ammonite assemblages at the top of the lower Maastrichtian and in the upper Maastrichtian but the youngest ammonites disappear about $10 \mathrm{~m}$ below the $\mathrm{K} / \mathrm{T}$ boundary.

Indeed, no $\mathrm{K} / \mathrm{T}$ sequence is known where the ammonites survive to the massextinction horizon'. The inoceramids at least disappear at a recognized boundary, defined by the demise or evolutionary change of other organisms. The end of the ammonites cannot be correlated with any other biotic event. Although the gradual decline of the ammonites in the Upper Cretaceous has long been recognized ${ }^{2}$, it was previously believed that their final demise was a result of the mass extinction.

Another group of molluscs that show an abnormal pattern of extinction during the Maastrichtian are the benthonic rudists, a group of reef-building bivalves that some- times reached gigantic proportions. For example, the Maaastrichtian species Titanosarcolites giganteus reached a maximum length of $2 \mathrm{~m}$, and Durania nicholasi was the size of a large waste-paper basket. The rudists were limited to shallow, tropical seas and reached their greatest diversity during the Maastrich$\operatorname{tian}^{3-5}$. Yet they were extinct by the beginning of the Tertiary, and many rudist groups perished before the $\mathrm{K} / \mathrm{T}$ boundary. In Jamaica, for example, there is very good evidence that the last rudists were killed by volcanic, rather than extraterrestrial, events before the end of the Cretaceous.

It has been suggested ${ }^{6}$ that the rudists were largely extinct one or two million years before the $\mathrm{K} / \mathrm{T}$ mass extinction and that their latest Maastrichtian faunas were small and isolated. If so, then they may have been particularly susceptible to changes in the environment, which could have lead to their demise at the end of the Cretaceous. The most important trait for the survival of a large taxonomic group at the time of a mass extinction appears to have been a broad geographical range, with members of the group inhabiting numerous basins ${ }^{7}$. Thus the late Maastrichtian extinction (for which the mechanism is not known) greatly reduced the diversity and range of the rudists, so that the weakened stock was not strong enough to survive the effects of the $\mathrm{K} / \mathrm{T}$ bolide impact.

If we look at the $\mathrm{K} / \mathrm{T}$ impact as an event that destroyed certain already weakened stocks, we still do not have an explanation for the process of the earlier Maastrichtian extinctions. The late Cretaceous-early Tertiary, however, was a time of global tectonic activity, with events such as the opening of the Atlantic affecting global ocean-water circulation and both creating and destroying habitats. Perhaps this was the true coffin-maker of mass extinction, with the $\mathrm{K} / \mathrm{T}$ bolide driving the final nail home for many groups

\footnotetext{
1. Ward, P., Wiedmann, J. \& Mount, J.F. Geology 14, 899 903 (1986).

2. Kennedy, W.I. in Patterns of Evolution, as Illustrated by the Fossil Record (ed. Hallam, A.) 251-304 (Elsevier, Amsterdam, 1977)

3. Masse, J.-P.\& Philip, J. Bull. Centres Rech. Explor.-Prod. Elf-Aquitaine 10, 437-456 (1986)

Jones, D.S. \& Nicol, N. J. Paleont. 60, 107-115 (1986)

5. Nicol, D. Nautilus 100, 69-71 (1986).

6. Kauffman, E.G. in Cretaceous-Tertiary Boundary Events $I$ (eds Christensen, W.K. \& Birkelund, T.) 29-37 (University of Copenhagen, 1979)

7. Jablonski, D. Abstr. 3rd Int. Congr. Syst. Evolut. Biol., 84 (1985)
}

Stephen K. Donovan is in the Department of Geology, University of the West Indies, Mona, Kingston 7, Jamaica. 